\title{
The role of new stress protectors in the formation of production process of oat culture during cultivation in anthropogenically polluted areas
}

\author{
Yuliya M. Andriyanova ${ }^{1, *}$, Irina $V$. Sergeyeva ${ }^{1}$, Nataliya N. Gusakova ${ }^{1}$,and Yuliya M. \\ Mokhonko ${ }^{1}$ \\ ${ }^{1}$ Saratov State Agrarian University named after N.I. Vavilov, Department of Botany, Chemistry and \\ Ecology, 410012 Saratov, Russia.
}

\begin{abstract}
Stress protectors (adaptogens) are among the most important factors that regulate growth processes at all stages of plant development. This article presents results of field studies of the effect of new synthetic plant growth regulators of stress protectors (adaptogens) on the elements of productivity and yield of spring oats of the Skakun variety. The obtained results during the research showed that all the studied derivatives of peredazinones are adaptogens and they contribute to an increased productivity and increased yield of spring oats. We studied the effect of presowing treatment of seeds with new synthetic plant growth regulators of stress protectors on the quality indicators of cereal production of Skakun oats (protein, starch and amylolytic enzymes content in the cereal). Presowing treatment of oat seeds increases the amount of protein in the cereal up to $15 \%$, starch - up to $25 \%$, amylase - up to $20 \%$. We proved the ability of stress protectors to minimize the negative impact of heavy metals (lead, zinc) on agrophytocenoses, which will make it possible to obtain environmentally friendly cereal products when cultivating oats in anthropogenically polluted areas of the Saratov Oblast.
\end{abstract}

\section{Introduction}

Oats is a significant food and feed crop in the Russian Federation. Oat productivity is significantly reduced due to environmental pollution. Therefore, the issue of obtaining a high stable grain crop that meets the environmental safety criteria arises at the present. At the present stage of the agricultural technologies' development, application of synthetic plant growth regulators is an environmentally safe and cost-effective way to increase crop yields. Usage of synthetic plant growth regulators for pre-sowing treatment of seeds even in small doses leads to significant changes in morphological and physiological processes in plants. New synthetic regulators of plant growth and development have high adaptogenic and

\footnotetext{
* Corresponding author: zay-84-84@mail.ru
} 
biological effectiveness in environmental pollution, which was established experimentally [1-10].

Therefore, the study of influence of synthetic plant growth regulators on the yield and the actual quality of the crop yield, taking into account specific soil and climatic conditions and the state of the environment, is very relevant.

The research's objective is to study the influence of new synthetic plant growth regulators on the formation of production process of oats culture that is cultivated in the anthropogenically polluted areas of the Saratov Oblast.

\section{Materials and methods}

The field research has been carried out for ten years on the fields of the private limited company "Perspektivnoye" and the private limited company "Summer-2002" of the Tatishchevsky district of the Saratov Oblast.

The research's object was the commercial variety of spring oats - Skakun.

Oats seeds were treated before sowing with preparations of new synthetic plant growth regulators (SPGR) in recommended doses $[2,11]$ :

1. 4-(4-methoxybenzylidene)-4.5-dihydro-6-tolyl-pyridazin-3-one-SPGR ${ }^{1}$.

2. 4-(4-hydroxy-3-methoxybenzyl-den)-4.5-dihydro-6-tolyl-pyridazin-3-one - SPGR 2 .

Immunocytophyte $\left(\mathrm{SPGR}^{3}\right)$ was used as a standard.

In accordance with the method of B.N. Dospekhov, we organized field studies and observations, as well as laboratory experiments and statistical processing of the obtained results during the studies [12]. Field experiments, in plots with an accounting area of $50 \mathrm{~m}^{2}$, were conducted in 4-fold repetition. Research variants are presented in Table 1

Table 1. Research variants.

\begin{tabular}{|c|c|c|c|}
\hline 1. Control ${ }^{1}$ & $11 . \mathrm{Zn}^{+2 \cdot} \cdot 10^{-5 \%} \%$ & 21. $\mathrm{SPGR}^{1}+\mathrm{Pb}^{+2} 10^{-3} \%$ & 31. $\mathrm{SPGR}^{2}+\mathrm{Pb}^{+2} 10^{-5 \%}$ \\
\hline 2. $\mathrm{SPGR}^{3}$ & 12. $\mathrm{Zn}^{+2} 10^{-6 \%} \%$ & 22. $\mathrm{SPGR}^{1}+\mathrm{Pb}^{+2} 10^{-40} \%$ & 32. $\mathrm{SPGR}^{2}+\mathrm{Pb}^{+2} 10^{-6 \%}$ \\
\hline 3. SPGR $^{1}$ & 13. $\mathrm{SPGR}^{3+} \mathrm{Pb}+210^{-3} \%$ & 23. $\mathrm{SPGR}^{1}+\mathrm{Pb}^{+2} 10^{-5 \%}$ & 33. $\mathrm{SPGR}^{2}+\mathrm{Zn}^{+2} \cdot 10^{-3} \%$ \\
\hline 4. $\mathrm{SPGR}^{2}$ & 14. $\mathrm{SPGR}^{3+} \mathrm{Pb}+2 \cdot 10^{-4} \%$ & 24. $\mathrm{SPGR}^{1}+\mathrm{Pb}^{+2} 10^{-6} \%$ & 34. $\mathrm{SPGR}^{2}+\mathrm{Zn}^{+2} \cdot 10^{-4} \%$ \\
\hline 5. $\mathrm{Pb}^{+2} 10^{-3 \%} \%$ & 15. $\mathrm{SPGR}^{3+} \mathrm{Pb}+210^{-5 \%}$ & 25. $\mathrm{SPGR}^{1}+\mathrm{Zn}^{+2} \cdot 10^{-3} \%$ & 35. $\mathrm{SPGR}^{2}+\mathrm{Zn}^{+2} \cdot 10^{-5} \%$ \\
\hline 6. $\mathrm{Pb}^{+2} \cdot 10^{-40} \%$ & 16. $\mathrm{SPGR}^{3+} \mathrm{Pb}+210^{-6 \%}$ & 26. $\mathrm{SPGR}^{1}+\mathrm{Zn}^{+2} \cdot 10^{-4} \%$ & 36. $\mathrm{SPGR}^{2}+\mathrm{Zn}^{+2} \cdot 10^{-6} \%$ \\
\hline 7. $\mathrm{Pb}^{+2} 10^{-5 \%}$ & 17. $\mathrm{SPGR}^{3+} \mathrm{Zn}+2 \cdot 10^{-3} \%$ & 27. $\mathrm{SPGR}^{1}+\mathrm{Zn}^{+2} \cdot 10^{-5} \%$ & \multirow{4}{*}{ 37. Control ${ }^{2}$} \\
\hline $8 . \mathrm{Pb}^{+2} \cdot 10^{-6 \%} \%$ & 18. $\mathrm{SPGR}^{3+} \mathrm{Zn}+2 \cdot 10^{-4} \%$ & 28. $\mathrm{SPGR}^{1}+\mathrm{Zn}^{+2} \cdot 10^{-6} \%$ & \\
\hline 9. $\mathrm{Zn}^{+2} \cdot 10^{-3} \%$ & 19. $\mathrm{SPGR}^{3+} \mathrm{Zn}+2 \cdot 10^{-5 \%}$ & 29. $\mathrm{SPGR}^{2}+\mathrm{Pb}^{+2} 10^{-3} \%$ & \\
\hline 10. $\mathrm{Zn}^{+2} \cdot 10^{-4 \%} \%$ & 20. $\mathrm{SPGR}^{3}+\mathrm{Zn}^{+2} \cdot 10^{-6 \%}$ & 30. $\mathrm{SPGR}^{2}+\mathrm{Pb}^{+2} 10^{-4 \%} \%$ & \\
\hline
\end{tabular}

Crop cultivation technology was in line with the regional recommendations.

Sampling of oat plants was carried out when the plants were in a "critical period" and were distinguished by a high degree of responsiveness of their functional systems to various factors (in the booting stage, the heading panicles stage). Leaves of only the first and second tier were selected the for research, which have already completed their growth and fully reflect the state of the plant organism as a whole.

\section{Results and discussion}

During the research it was found that seed treatment with SPGR solutions (No. 2-4) contributed to an increase in germination by $14.0 \%\left(\mathrm{SPGR}^{3}\right)-36.2 \%\left(\mathrm{SPGR}^{2}\right)$. Due to the use of lead dinitrate (No. 5-8) and zinc sulphate (No. 9-12) in high concentrations, the germination rate of oats decreased by $16.0-21.4 \%$ (No. 5, 6) and $17.9 \%$ (No. 9), and when using dinitrate low synthetic concentrations of lead and zinc sulphate, these synthetic plant 
growth regulators showed insignificant stimulating effects and increased germination by $8.8 \%$ (No. 8) and 3.7\% (No. 10) compared to the control variant.

After treating oat seeds with combinations of SPGR $+\mathrm{Pb}^{+2}$ and SPGR $+\mathrm{Zn}^{+2}$, the negative effects of the lead cations $\left(\mathrm{Pb}^{+2}\right)$ and zinc $\left(\mathrm{Zn}^{+2}\right)$ were neutralized in all of the studied concentrations, which contributes to an increase in seed germination by $5.0-14.3 \%$ (No. 21 24, 29-32) and 3.6-21.4\% (No. 25-28, 33-36), respectively, compared to the control variant. At the same time, $\mathrm{SPGR}^{3}$ smoothed out the toxic effects of lead and zinc cations only at a concentration of $10^{-6 \%}$ (No. 16 and 20) (Fig. 1).

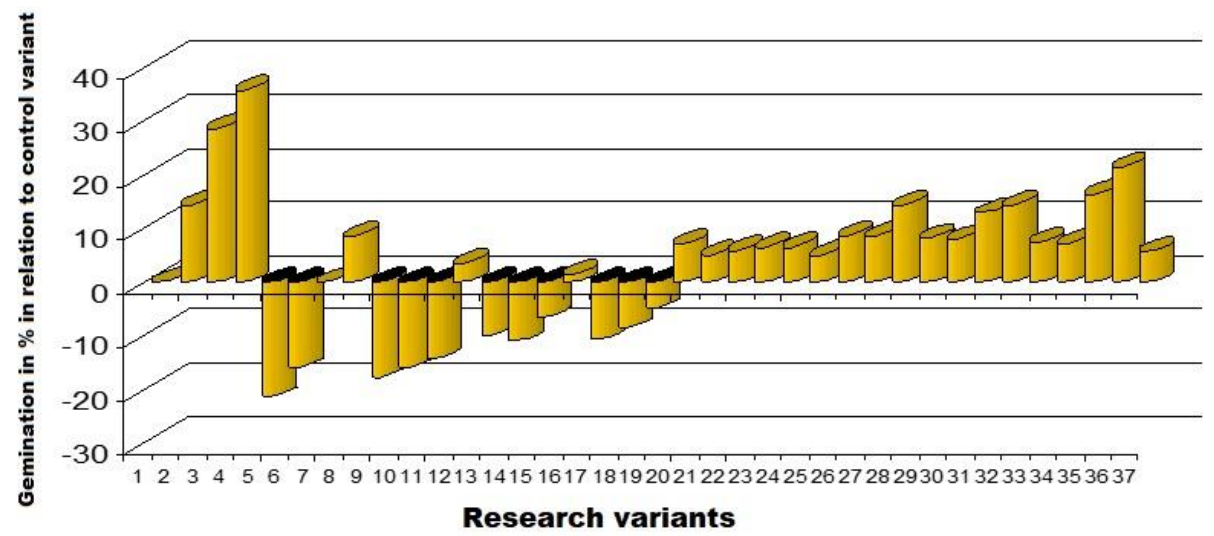

Fig. 1. Effect of SPGR, lead cations $\left(\mathrm{Pb}^{+2}\right)$ and zinc cations $\left(\mathrm{Zn}^{+2}\right)$ on oat germination.

The effects of SPGR, lead $\left(\mathrm{Pb}^{+2}\right)$ and zinc $\left(\mathrm{Zn}^{+2}\right)$ cations on the development of the organogenesis stages of spring oats were studied during the research:

- pre-sowing treatment of oat seeds with "pure" solutions of synthetic plant growth regulators led to more active emergence of seedlings (4 days earlier), the onset of tillering stages ( 6 days), the booting stage ( 9 days), the heading stage (12 days), milky-wax ripeness (16 days), in comparison with the control variants;

- treatment of oat seeds before sowing with solutions of $\mathrm{Pb}^{+2}\left(10^{-3}-10^{-5 \%}\right)$ and $\mathrm{Zn}^{+2}\left(10^{-}\right.$ ${ }^{3}-10^{-6 \%} \%$ ) delayed the onset of all stages of organogenesis for 5-9 days;

- when using solutions of lead dinitrate $\left(\mathrm{Pb}^{+2}\right)$ at a concentration of $10^{-6 \%}$, the onset of all stages of organogenesis coincided with the control variant;

- a reduction in the growing season and smoothing of the negative effect of lead and zinc cations on growth processes was observed with the use of combinations SPGR $+\mathrm{Pb}^{+2}$ and $\mathrm{SPGR}+\mathrm{Zn}^{+2}$.

Pre-sowing seed treatment with "pure" SPGR solutions increased the leaf area. Application of solutions of lead dinitrate and zinc sulphate in all concentrations contributed to a decrease in the leaf surface area at all stages of development, compared with the control variant.

Comparison of the protective effect of the studied synthetic growth regulators on the leaf area allows to isolate the $\mathrm{SPGR}^{2}$ compound. The industrial product - immunocytophyte $\left(\mathrm{SPGR}^{3}\right)$ did not have a levelling effect on lead cations $\left(\mathrm{Pb}^{+2}\right)$, and the toxic effect of zinc cations $\left(\mathrm{Zn}^{+2}\right)$ decreased by only $4.0-10.0 \%$ (No. 17-20) (Fig. 2). 


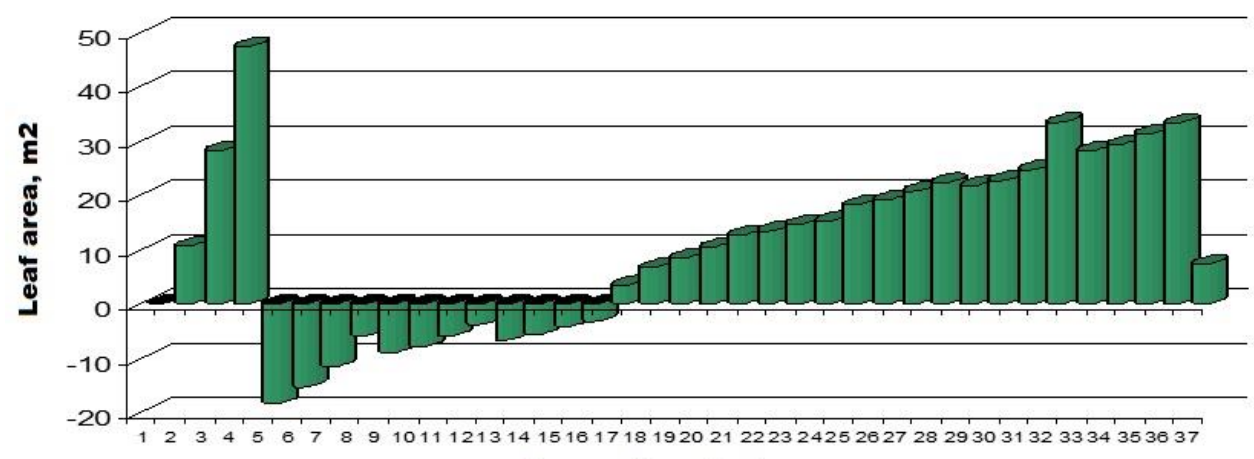

Research variants

Fig. 2. Effect of SPGR, lead $\left(\mathrm{Pb}^{+2}\right)$ and zinc $\left(\mathrm{Zn}^{+2}\right)$ cations on oat leaf area.

The photosynthetic potential of plants depends significantly on the leaf surface area and changes during ontogenesis, affecting the resistance of plants to many stress factors.

The effect of the SPGR compound on the photosynthetic potential of oat plants was similar to its effect on the development of the leaf surface:

- the use of SPGR in its "pure" form contributed to an increase in the photosynthetic potential by $10.5 \%\left(\mathrm{SPGR}^{1}\right)-44.6 \%\left(\mathrm{SPGR}^{2}\right)$, compared with the control variant;

- treatment with solutions of lead and zinc in all concentrations during the entire growing season negatively affected the photosynthetic potential, because its value decreased by 15.4$21.7 \%$ (No. 5-8) and 19.5-23.8\% (No. 9-12), respectively;

- synthetic plant growth regulators (SPGR) in all of the studied combinations with lead $\left(\mathrm{Pb}^{+2}\right)$ and zinc $\left(\mathrm{Zn}^{+2}\right)$ cations smoothed out the negative effect of lead and zinc cations by an average of 4.7-24.6\% (No. 21-24, 29-32) and 10.6-25.3\% (No. 25-28, 33-36), respectively;

- immunocytophyte $\left(\mathrm{SPGR}^{3}\right)$ did not show a levelling effect with respect to lead cations.

We studied the effect of pre-sowing treatment of oat seeds with solutions of SPGR, lead cations $\left(\mathrm{Pb}^{+2}\right)$, zinc $\left(\mathrm{Zn}^{+2}\right)$ and their combinations (SPGR $+\mathrm{Pb}^{+2}$ and SPGR $\left.+\mathrm{Zn}^{+2}\right)$ on the number of grains in a panicle, grain weight with panicles, weight of 1000 grains, the number of spikelets in a panicle, the height of plants.

After pre-sowing treatment of oat seeds with synthetic plant growth regulators in oat panicles, an average of $100.6\left(\mathrm{SPGR}^{1}\right)-110.4\left(\mathrm{SPGR}^{2}\right)$ caryopses were observed with a total grain weight of $3.3\left(\mathrm{SPGR}^{1}\right)-3.5 \mathrm{~g}\left(\mathrm{SPGR}^{2}\right)$; the grain was formed large and complete. The grain, which was obtained as a result of treating of oat seeds with solutions of lead dinitrate and zinc sulphate, was small and puny, in this case, the grain weight from the panicle decreased by $24.0-28.0 \%$ and $16.0-22.0 \%$, respectively, as compared to the control variant. When using the growth regulator $\mathrm{SPGR}^{2}$ in combination with all concentrations of lead dinitrate and zinc sulphate, the control variant exceeded the number of grains in a panicle by 12.4-29.5\% (No. 29-32) and 30.9-45.8\% (No. 33-36); weight grains from a panicle by 8.020.0\% (No. 29-32) and 6.0-14.0\% (No. 33-36), respectively. However, when using combinations of SPGR ${ }^{1}$ with lead cations $\left(\mathrm{Pb}^{+2}\right)$ and zinc $\left(\mathrm{Zn}^{+2}\right)$, the toxic effects of lead cations were not levelled out. The decrease in the negative effect of zinc cations was only at concentration of $10^{-6} \%$ to the level of the control variant. No levelling effect was achieved, when we used combinations of solutions of lead dinitrate $\left(\mathrm{Pb}^{+2}\right)$ and zinc sulphate $\left(\mathrm{Zn}^{+2}\right)$ with the immunocytophyte product $\left(\mathrm{SPGR}^{3}\right)$.

Weight of 1000 oat grains in our studies varied from $20.3 \mathrm{~g}$ (when using lead cations) to $37.8 \mathrm{~g}$ (when using SPGR ${ }^{2}$ ). After pre-sowing seed treatment with SPGR solutions, oat yields ranged from 2.43 ( $\mathrm{SPGR}^{1}$ compound) to $2.55 \mathrm{t} / \mathrm{ha}$ (SPGR ${ }^{2}$ compound) compared with the control variant $(1.50 \mathrm{t} / \mathrm{ha})$. Application of immunocytophyte caused an increase in the oats 
yield by $0.51 \mathrm{t} / \mathrm{ha}(34.0 \%)$ compared with the control variant. However, the treatment of oat seeds with solutions of lead dinitrate and zinc sulphate in concentrations of $10^{-3}-10^{-5 \%}$ reduced the yield by 18.0-32.0 and 5.3-24.0\%, respectively, compared to the control variant. A concentration of $10^{-6 \%}$ of lead dinitrate and zinc sulphate exerted a slight stimulating effect, exceeding the productivity index by $0.10(6.6 \%)-0.15 \mathrm{t} / \mathrm{ha}(10 \%)$, respectively (Fig. $3)$.

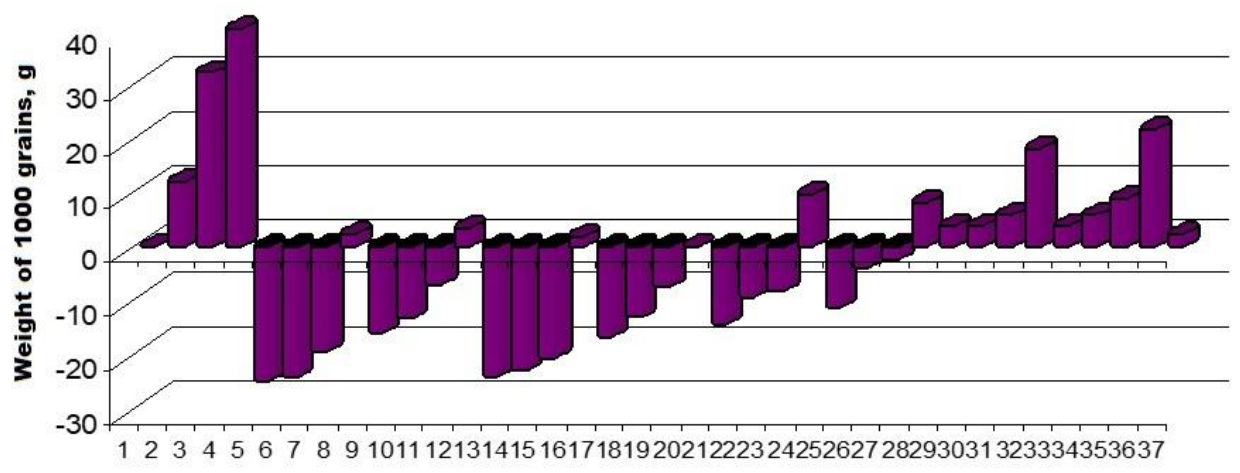

Research variants

Fig. 3. Effect of SPGR, lead $\left(\mathrm{Pb}^{+2}\right)$ and zinc $\left(\mathrm{Zn}^{+2}\right)$ cations on weight of 1000 grains.

Soaking the seed in solutions of SPGR $+\mathrm{Pb}^{+2}$ and SPGR $+\mathrm{Zn}^{+2}$ showed the following results (Fig. 4):

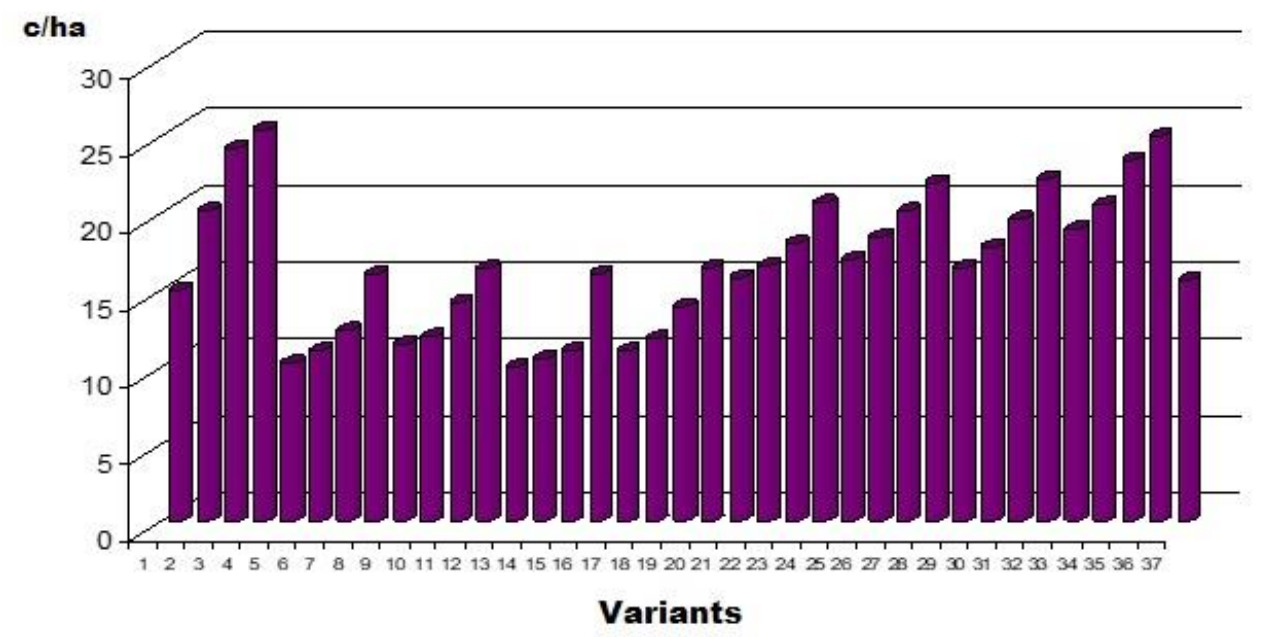

Fig. 4. Effect of SPGR, lead $\left(\mathrm{Pb}^{+2}\right)$ and zinc $\left(\mathrm{Zn}^{+2}\right)$ cations on oat yield.

- SPGR ${ }^{3}$ compound in combination with lead and zinc smoothed out the inhibitory effect of heavy metals only at a concentration of $10^{-6 \%}$ and contributed to the yield increase in comparison with the control variant in the amount of $0.10(6.6 \%)-0.15 \mathrm{t} / \mathrm{ha}(10.0 \%)$;

- combination of lead and zinc cations with $\mathrm{SPGR}^{2}$ reduced their negative effect and increased the oats yield by $0.08-0.57 \mathrm{t} / \mathrm{ha}$ (by $5.3-38.0 \%$ ) and $0.20-0.72 \mathrm{t} / \mathrm{ha}$ (by $13.3-46.6 \%$ ), respectively;

- the best levelling effect was observed when using the $\mathrm{SPGR}^{2}$ compound, which contributed to $0.15-0.73(10.0-48.6 \%)$ and $0.39-1.00$ t/ha $(26.0-66.6 \%)$ of yield increasing. 


\section{Conclusion}

We have revealed significant effectiveness of the use of stress protectors (growth-promoting products - derivatives of peredazinones) for the pre-sowing treatment of oat seeds. It was established that the pre-sowing treatment of oat seeds enhanced growth and physiological and biochemical processes, levelled the toxic effect of zinc and lead ions in the studied concentration ranges. The traditional technology of oats cultivation in anthropogenically polluted areas was modernized in order to collect high-quality products (environmentally friendly products) and reduce energy and material costs.

\section{References}

1. Yu. M. Andriyanova, N. N. Gusakova, Yu. M. Mokhonko, The Agrarian Scientific Journal 8, 3 (2016)

2. Yu. M. Andriyanova, I. V. Sergeeva, N. N. Gusakova, Yu. M. Mohonko. The Agrarian Scientific Journal 3, 8 (2016)

3. I. V. Sergeeva, Yu. M. Andriyanova, N. N. Gusakova, Yu. M. Mohonko, The Agrarian Scientific Journal 5, 3-8 (2016)

4. T. S. Kolmykova, A. S. Lukatkin, Agrohimia 1, 83 (2012)

5. I. I. Seregin, Cink, selen i regulyatory rosta v agrocenoze [Zinc, selenium and growth regulators in agrocenosis] (Prospect, Moscow, 2018)

6. O. G. Sinyashin, O. A. Shapoval, M. M. Shulaeva, Pladorodie 5, 38 (2016)

7. C. Qingjun, G. Li, D. Lamine, Y. Fentuan, Y. Liang, C. Jinhu, S. Fengbin, Romanian Agricultural Research 33, 217 (2016)

8. A. Széles, É. Horváth, A. Vad and E. Harsányi, Emir. J. Food Agric. 30, 764 (2018)

9. S. Korica, Chilean journal of agricultural research 79, 17 (2018). DOI: 10.4067/S071858392019000100017

10. Ya. V. Drevko, Sintez $i$ svojstva benzodigidroselenohromenov $i$ solej benzogidroselenohromiliya [Synthesis and properties of benzodihydroselenochromenium and salts of benzohydroselenochromilium] (Saratov State University, Saratov, 2009)

11. B. A. Dospekhov, Metodika polevogo opyta s osnovami statisticheskoj obrabotki rezul'tatov issledovanij [The methodology of field experience with the basics of statistical processing of research result] (Agropromizdat, Moscow, 1985) 